\title{
Synthetic estrogens, their presence in aquatic ecosystems and effects on biota
}

Synthetic estrogens are endocrine disrupting compounds that might be in water bodies and, consequently, interfere in hormonal, metabolic and reproductive functions of organisms exposed. This study aims to analyze the international scientific literature about those chemicals through a systematic and narrative review. The investigated estrogens were 17a-ethinylestradiol (EE2), Mestranol (MeEE2), Diethylstilbestrol (DES) and Dienestrol (DNS), which are widely present in pharmaceuticals, consumed and disposed in the environment. For this review, only scientific papers, published from 1990 to 2019 , were considered. They were collected in ScienceDirect, PubMed and Scielo online platforms. Introductory information about the compounds, such as their chemical characteristics and use in society were described, as their occurrence in aquatic ecosystems and effects on biota, reported by environmental assessments and ecotoxicological tests, respectively. According to this study, China is the major contributor in quantitative terms, counting 21 articles about synthetic estrogens. Some hormones demonstrated to be more investigated than others; moreover, the increasing of research about those emerging contaminants was noticed. Additionally, Brazilian water bodies revealed to have the highest concentrations, which should encourage critical thinking on its insufficient environmental management. The study also highlights the importance of scientific research expansion and its implementation on truly effective public policies for aquatic ecosystem conservation.

Keywords: Disruptor; Endocrine; Environment; Pollution; Hormone.

\section{Estrógenos sintéticos, sua presença em ecossistemas aquáticos e efeitos na biota}

\begin{abstract}
Estrógenos sintéticos são disruptores endócrinos que podem estar presentes em corpos d'água e, consequentemente, interferir em funç̃os hormonais, metabólicas e reprodutivas de organismos expostos. Este estudo busca analisar a literatura científica internacional sobre tais compostos através de uma revisão narrativa e sistemática. Os estrógenos investigados foram 17a-etinilestradiol (EE2), Mestranol (MeEE2), Dietilestilbestrol (DES) e Dienestrol (DNS), que estão amplamente presentes em fármacos, sendo consumidos e dispostos no ambiente. Para esta revisão, apenas artigos científicos, publicados entre 1990 e 2019 foram considerados, tendo sido coletados nas plataformas online ScienceDirect, PubMed e Scielo. Informaç̃̃es introdutórias sobre os compostos, como características químicas e uso em sociedade foram descritas, assim como sua ocorrência em ecossistemas aquáticos e efeitos na biota, reportados por monitoramentos ambientais e testes ecotoxicológicos, respectivamente. De acordo com o presente estudo, a China se mostrou como maior contribuinte em termos quantitativos, somando 21 artigos sobre estrógenos sintéticos. Alguns hormônios demonstraram ser mais investigados do que outros e o aumento de pesquisas a respeito destes contaminantes emergentes foi notado. Além disso, os corpos d'água brasileiros revelaram ter as maiores concentrações, o que deve encorajar uma reflexão crítica sobre sua gestão ambiental insuficiente. 0 estudo também destaca a importância da expansão de pesquisas científicas e sua implementação em políticas públicas realmente efetivas na conservação de ecossistemas aquáticos.
\end{abstract}

Palavras-chave: Disruptor; Endócrino; Poluição; Ambiental; Hormônio.

Topic: Química Agrícola e Ambiental

Reviewed anonymously in the process of blind peer.
Received: 02/01/2021

Approved: 26/01/2021

Débora Maria Carvalho da Silva (iD

Universidade Federal do Ceará, Brasil

http://lattes.cnpq.br/5769016775456349

http://orcid.org/0000-0003-2645-357X

dmcarvalho97@gmail.com

Cléber Domingos Cunha da Silva (iD)

Universidade Federal do Ceará, Brasil

http://lattes.cnpq.br/4101539380397371

http://orcid.org/0000-0002-7362-9876

domingoscunha@ufc.br

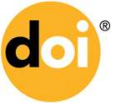

DOI: 10.6008/CBPC2179-6858.2021.001.0008
Referencing this:

SILVA, D. M. C.; SILVA, C. D. C.. Synthetic estrogens, their presence in aquatic ecosystems and effects on biota. Revista Ibero Americana de Ciências Ambientais, v.12, n.1, p.84-101, 2021. DOI:

http://doi.org/10.6008/CBPC2179-6858.2021.001.0008 


\section{INTRODUCTION}

Environmental pollution is a great concern in contemporary society. It affects populations' health and quality of life, besides being one of the major contributors to species extinction alongside habitat destruction and introduction of invasive organisms (BAIRD, 2008; PRIMACK et al., 2001). Pollution's magnitude reflects on water resources, affected by municipal and industrial wastewater discharges. Despite the required treatment, effluents might still contain harmful chemicals such as endocrine disrupting compounds (EDCS) (FERREIRA, 2013; REIS FILHO et al., 2007).

Defined as exogenous substances that cause adverse health effects on an intact organism, or its progeny, consequent to changes in endocrine functions (EC, 1996), endocrine disrupting compounds comprise a wide range of chemicals, including steroid hormones, derived from cholesterol (ADEEL et al., 2017), and synthetic composites, capable of mimicking or inhibiting estrogen and testosterone action (KIYAMA et al., 2015). Synthetic hormones, which are called environmental estrogens and androgens too, have a wide application in society, including menopause treatment, contraception and livestock growth promotion (ALBERO et al., 2013), which contributes to their availability in ecosystems and biota exposure. What environmental impacts do those compounds have? Answering that requires comprehension of hormones physiological actions.

Estrogen and progesterone are endogenous hormones that promote development and operation of female reproductive system, involved in the metabolism of lipids, minerals, carbohydrates and proteins. They have important functions in men as well, determining effects on bones, spermatogenesis and behaviour (LOOSE et al., 2010). Likewise, testosterone plays important roles in men such as the development of reproductive tissues, regulation of bone and muscles mass (WEIN, 2013). The effects of endocrine disruptors relate to hormone biosynthesis, metabolism, transport and mechanism of action on both receptor and postreceptor levels (HAMPL et al., 2016). Hence, EDCs have become a frequently discussed topic in research papers that evaluate their presence in natural water bodies and whether they influence wildlife (LIU et al., 2020; HUANG et al., 2019; DORABAWILA et al., 2005; IWANOWICZ et al., 2016; ANNAMALAl et al., 2015; BERTIN et al., 2020).

Despite the wide assessment of natural hormones, synthetic estrogens as $17 \alpha$-ethinylestradiol (EE2), Mestranol (MeEE2), Diethylstilbestrol (DES) and Dienestrol (DNS) are targets of investigations as well, held in numerous countries from most continents. Thus, they became relevant objects of international studies (ARMSTRONG et al., 2016; ORN et al., 2016; UIRAPONG, 2017; POJANA et al., 2007; LEl et al., 2009; DAMKJAER et al., 2018).

In view of these considerations, this paper aims to review the current knowledge about the abovecited synthetic hormones, focusing on their occurrence in aquatic ecosystems and their effects on biota, reported by international scientific papers. 


\section{MATERIALS AND METHODS}

The analysis of international scientific literature was held through ScienceDirect, PubMed and Scielo (Scientific Electronic Library Online) platforms using a combination of key words (Table 1). Only scientific papers about 17 $\alpha$-ethinylestradiol, Mestranol, Diethylstilbestrol and Dienestrol published from 1990 to 2019 were considered for the systematic review. The pollutants investigation simply considered the environmental perspective of field researches. Therefore, reviews, descriptive studies of analytical methods and clinical assays regarding other aspects of the composites were not selected.

Table 1: Key words used for paper browse.

\begin{tabular}{|l|l|l|l|}
\hline COMPOUND & PLATFORM & SUBJECT & Effects on biota \\
\cline { 3 - 4 } & & Occurrence in aquatic ecosystems & Ethinylestradiol, effects, biota \\
\hline \multirow{4}{*}{ EE2 } & ScienceDirect & Ethinylestradiol, occurrence, sediment & Ethinylestradiol, effects, biota \\
\cline { 2 - 4 } & PubMed & Ethinylestradiol, occurrence, sediment & Ethinylestradiol \\
\cline { 2 - 4 } & Scielo & Ethinylestradiol & Mestranol, effects, organism \\
\hline \multirow{4}{*}{ DEEE2 } & ScienceDirect & Mestranol, occurrence, environment & Mestranol, effects \\
\cline { 2 - 4 } & PubMed & Mestranol, occurrence, environment & Mestranol \\
\cline { 2 - 4 } & Scielo & Mestranol & Diethylstilbestrol, effects, ecotoxicology \\
\hline \multirow{3}{*}{ DNS } & ScienceDirect & Diethylstilbestrol, occurrence, sediment, water & Diethylstilbestrol, effects, ecotoxicology \\
\cline { 2 - 4 } & PubMed & Diethylstilbestrol, occurrence, sediment, water & Diethylstilbestrol \\
\cline { 2 - 4 } & Scielo & Diethylstilbestrol & Dienestrol, effects \\
\cline { 2 - 4 } & ScienceDirect & Dienestrol, environment & Dienestrol \\
\cline { 2 - 4 } & PubMed & Dienestrol & Dienestrol \\
\cline { 2 - 3 } & Scielo & Dienestrol & \\
\hline
\end{tabular}

Additionally, an introductory research was elaborated to support a deeper discussion about the contaminants. Its data sources include papers, monographs and official reports from renowned institutes and authorities. Moreover, PubChem and Drugbank websites were consulted for chemical information. The opening section concerns the pollutants' characteristics and use in society and it is followed by the systematic review itself, which is a critical examination of studies about synthetic hormones, especially their presence in nature along the years and potential harms in wildlife. Considering the review, we expect to evaluate science courses, to discuss possible gaps in our current knowledge about EDCs and future perspectives for it as well.

\section{RESULTS AND DISCUSSION}

Recognition of human activities that contribute to endocrine disrupting compounds availability in nature is important to understand synthetic estrogens sources. However, because of the high amount of EDCs, a direct and more specific analysis was considered more suitable for this work. Consequently, the next sections contain separate and specific information about $17 \alpha$-ethinylestradiol, Mestranol, Diethylstilbestrol and Dienestrol. Their entry in society and their characteristics are presented with the support of a simpler review (the introductory research previously cited), then their occurrence in aquatic ecosystems and their effects on biota, which are the focus of this paper, are accompanied by the number of identified and selected records. 


\section{7a-ethinylestradiol}

Initially commercialized as an oral contraceptive in the 1960s, 17 $\alpha$-ethinylestradiol (EE2) is currently used to treat menopause symptoms, for hormone therapy in female with hypogonadism and to increase livestock productivity too (DHONT, 2010; LUCENA, 2013; ARIS et al., 2014). 17 $\alpha$-ethinylestradiol has been present in oral contraceptives (OCs) with varied doses over the years. Nowadays, they typically contain from 15 to $35 \mu \mathrm{g}$ of EE2 (HAMPSON, 2020). United Nations estimate that 842 million women of reproductive age use modern methods of contraception, whereas 151 million consume pills, mostly in Europe, The Caribbean, Northern and Latin America, and Oceania (UN, 2019). Its widespread use contributes for EE2 presence in ecosystems, since natural expelling through wastewater discharges and runoff follows their ingestion.

Lipolytic nature of the compound reinforces its low solubility in water, which is indicated as $4.8 \mathrm{mg} / \mathrm{L}$ at 20 ㅇ ( LAl et al., 2000). Similar to natural hormone estradiol, $17 \alpha$-ethinylestradiol chemical formula is $\mathrm{C}_{20} \mathrm{H}_{24} \mathrm{O}_{2}$ (Picture 1). It is soluble in ethanol and its reported log $\mathrm{K}_{\text {ow }}$ ranges from 3.67 (KOVACEVIC et al., 2019) to 4.15 (REN et al., 2017). Its molecular weight is 296.40 .

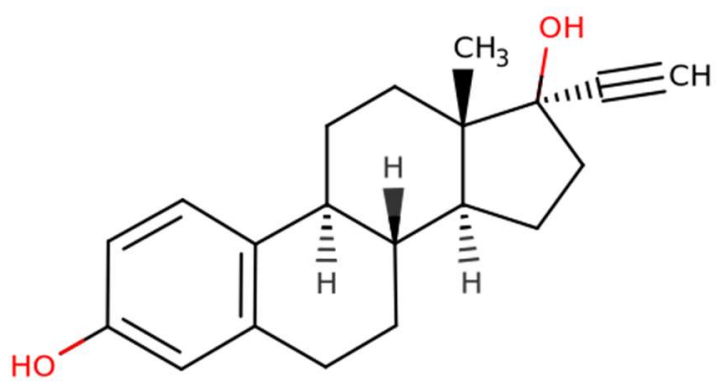

Picture 1: $17 \alpha$-ethinylestradiol.

Considering the above-mentioned chemical traits, chemical analysis of EE2, which is a hydrophobic organic compound, is mainly directed to sedimentary compartments. That is the motive of 'sediment' being one of the key words used in this review. It is where we expect to find the contaminants, considering their presence in the ecosystem.

\section{$17 \alpha$-ethinylestradiol in aquatic ecosystems}

Inspection at ScienceDirect, PubMed and Scielo led to 504, 27 and 38 articles, respectively. Analysis of the synthetic hormone presence in organisms as replicates and papers that did not contemplate studies in natural ecosystems were disregarded. Moreover, investigations held in wastewater treatment plants were not considered either. Accordingly, 17 articles were appropriate for this review (Table 2).

The revised studies took place in China (nine studies), Brazil (6), Italy (1) and Malaysia (1). Concentration of $17 \alpha$-ethinylestradiol ranged from not detected to $4.073 \mathrm{ng} / \mathrm{L}$. The lowest level was registered as $0.3 \mathrm{ng} / \mathrm{L}$ in a Chinese river (Liu et al., 2015), while the highest one was in Brazilian waters (Montagner, Jardim, 2011). Most of the researches occurred in rivers (eleven studies), followed by estuaries 
(4), a bay (1), a lake (1) and a mangrove (1) environment.

Table 2: Presence of Ethinylestradiol in aquatic ecosystems.

\begin{tabular}{|c|c|c|c|}
\hline COUNTRY & MATRIX & CONCENTRATION & AUTHORS \\
\hline \multirow{6}{*}{ Brazil } & Water & $17-4073$ & MONTAGNER et al., (2011) \\
\hline & Sediment & $0.45-129.78$ & FROEHNER et al. (2012) \\
\hline & Sediment & 70.28 & PIMENTEL et al. (2016) \\
\hline & Sediment & $20 \pm 6.2-86.3 \pm 25.6$ & PUSCEDDU et al. (2019) \\
\hline & Sediment & $91.04-321.71$ & SANTOS et al. (2019) \\
\hline & Sediment & $90.92 \pm 8.32$ & MORAIS et al. (2019) \\
\hline \multirow{13}{*}{ China } & Water & $\mathrm{ND}-0.52$ & Ll et al. (2013) \\
\hline & Water & ND - 206.5 & \multirow{2}{*}{ HUANG et al. (2013) } \\
\hline & Sediment & ND - 21.2 & \\
\hline & Water & $0.3-5.9$ & LIU et al. (2015) \\
\hline & Water & ND -43.93 & \multirow{2}{*}{ YANG et al. (2015) } \\
\hline & Sediment & $N D-33.38$ & \\
\hline & Water & $4.09-16.85$ & WANG, ZHU (2017) \\
\hline & Water & $1.14-2.39$ & \multirow{2}{*}{ WANG et al. (2017) } \\
\hline & Sediment & $1.06-2,19$ & \\
\hline & Sediment & $8.2-16.9$ & LIU et al. (2018) \\
\hline & Water & ND - 17.112 & \multirow{2}{*}{ TAN et al. (2018) } \\
\hline & Sediment & ND - 17.9 & \\
\hline & Water & $0.391-0.523$ & ASHFAQ et al. (2019) \\
\hline \multirow{2}{*}{ Italy } & Water & ND - 34 & \multirow{2}{*}{ POJANA et al. (2007) } \\
\hline & Sediment & $12-41$ & \\
\hline \multirow{2}{*}{ Malaysia } & Water & ND -0.005 & \multirow{2}{*}{ PRAVEENA et al. (2019) } \\
\hline & Sediment & ND - 0.329E-4 & \\
\hline
\end{tabular}

In spite of EE2 intense use in society (probably it is the most used synthetic estrogen), it can be observed the small percentage of successful results during papers browsing. Perhaps, the use of more scientific platforms for this review would be necessary. Another possibility is to assume that the number of diagnosis of EE2 concentrations in aquatic environments is not proportional to its presence in daily life.

\section{Effects of $17 \alpha$-ethinylestradiol on biota}

The effects of endocrine disrupting compounds have been observed in reptiles, birds and mammals (BHANDARI et al., 2015; OTTINGER et al., 2015). Experimental tests in animals, reported by scientific literature, cooperate in defining a certain chemical as an EDC, which can lead to those compounds regularization, for the benefit of public health (TOPPARI, 2019). Ecotoxicological tests involving EE2 demonstrated that it can be from twice (in humans) to five times (in some fish species) more relatable to estrogen receptor, compared to estradiol (ARIS et al., 2014). Furthermore, EE2 has a high potential of bioaccumulation in ichthyofauna (LIU et al., 2017). Fish are exposed to $17 \alpha$-ethinylestradiol in contaminated environments and in aquaculture's monosex populations such as tilapia's (Oreochromis niloticus), even though $17 \beta$-estradiol is the preferred estrogen in sexual reversion induction (PANDIAN et al., 1995; HOGA et al., 2018).

Regarding human exposure to EE2, Salierno et al., (2009) presented degenerative effects as changes in reproductive behavior and development of secondary sexual characteristics in men. Moreover, contraindications of EE2 include carcinoma and neoplasia; although its carcinogenicity is not directly listed, $17 \alpha$-ethinylestradiol constitute combined oral contraceptives, which are listed as carcinogenic to humans 
(group 1), according to International Agency for Research on Cancer (IARC, 1999).

Systematic search for ecotoxicological tests in biota involving EE2 led to 350 (ScienceDirect), 21 (PubMed) and 38 (Scielo) articles. Studies about bioaccumulation, risk assessments as reviews and tests using mixtures of EE2 and other contaminants were not considered. Thus, 11 scientific papers were selected.

Table 3: Effects of $17 \alpha$-ethinylestradiol on biota.

\begin{tabular}{|c|c|c|c|}
\hline TEST ORGANISM & $\mathbf{C}$ & REPORTED EFFECTS & A \\
\hline $\begin{array}{l}\text { Drosophila } \\
\text { melanogaster }\end{array}$ & $\begin{array}{l}0.015 \% \text { and } \\
0.003 \%\end{array}$ & $\begin{array}{l}\text { Mortality; decrease in fertility; interference in gene } \\
\text { expression }\end{array}$ & BOVIER et al. (2018) \\
\hline L. catesbeianus & $10 \mathrm{ng} / \mathrm{L}$ & Tachycardia & SALLA et al. (2016) \\
\hline Salmo salar & $\begin{array}{l}0.04 \mathrm{nM}- \\
0.4 \mathrm{nM}\end{array}$ & $\begin{array}{l}\text { Increase in vitellogenin (VTG) levels; decrease in hepatic } \\
\text { proteins levels and hormone receptors (estrogen } \alpha \text { and } \\
\text { GHR) }\end{array}$ & BREVES et al. (2018) \\
\hline $\begin{array}{l}\text { Pimephales } \\
\text { promelas }\end{array}$ & $0.5 \mathrm{ng} / \mathrm{L}$ & Inhibition of eggs production & RUNNALLS et al. (2015) \\
\hline Chlorella vulgaris & \multirow[b]{2}{*}{$0.1 \mathrm{mg} / \mathrm{L}$} & \multirow[b]{2}{*}{ Increase in biomass; decrease in chlorophyll a levels } & \multirow[b]{2}{*}{ CZARNY et al. (2019) } \\
\hline $\begin{array}{l}\text { Scenedesmus } \\
\text { armatus }\end{array}$ & & & \\
\hline Mytilus trossulus & $50 \mathrm{ng} / \mathrm{dm}^{3}$ & Gonadal regression and atresia & SKJAERLUND (1992) \\
\hline $\begin{array}{l}\text { Oreochromis } \\
\text { mossambicus }\end{array}$ & $120 \mathrm{mg} / \mathrm{kg}$ & $\begin{array}{l}\text { Feminization; increase in gonadosomatic index (GSI) and } \\
\text { muscle fat }\end{array}$ & $\begin{array}{l}\text { LÁZARO-VELASCO et al. } \\
(2019)\end{array}$ \\
\hline Chironomus tentans & $1.6 \mathrm{mg} / \mathrm{L}$ & \multirow[b]{2}{*}{ Mortality and growth decrease } & \multirow[b]{2}{*}{ DUSSAULT et al. (2008) } \\
\hline Hyalella azteca & $\begin{array}{l}2.5 \quad \mathrm{mg} / \mathrm{L} \\
\text { and } \\
4.1 \mathrm{mg} / \mathrm{L}\end{array}$ & & \\
\hline M. galloprovincialis & \multirow{2}{*}{$\begin{array}{l}50- \\
500 \mathrm{ng} / \mathrm{L}\end{array}$} & \multirow{2}{*}{ Mortality and inhibition of gametes fertilization } & \multirow{2}{*}{ CAPOLUPO et al., (2018) } \\
\hline P. lividus & & & \\
\hline $\begin{array}{l}\text { Peromyscus } \\
\text { californicus }\end{array}$ & $0.1 \mathrm{ppb}$ & Changes in intestinal flora & JAVUREK et al. (2016) \\
\hline $\begin{array}{l}\text { Oreochromis } \\
\text { niloticus }\end{array}$ & $\begin{array}{l}250, \quad 500 \\
\text { and } \\
1000 \mathrm{ng} / \mathrm{L}\end{array}$ & $\begin{array}{l}\text { Malformation, behaviour change, development of intersex } \\
\text { fish }\end{array}$ & PASSOS NETO et al. (2019) \\
\hline
\end{tabular}

$\mathrm{C}=$ Concentration/ $\mathrm{A}=$ Author $(\mathrm{s})$

Insects, amphibian, fish, algae and marine invertebrates were submitted to ecotoxicological tests, while rats were tested in a toxicological assay. The concentrations of EE2 were varied, as the observed effects on organisms. Other studies mention change in social behaviors such as mating, increase in aggressiveness, induction to vitellogenin (VTG) production in male fish and inhibition of reproduction (VOLKOVA et al., 2015; CHEN et al., 2017; ZHA et al., 2008).

Comparing different studies when the doses and organisms are different is a limited approach, especially if the concentrations present in organisms that were exposed in 'natural' conditions are unknown. From the discharge of contaminants in water bodies to the estimation of toxic doses for aquatic living beings, there is a blank held by bioaccumulation and biomagnification processes. How exposed to EE2 is biota? Are the observed effects overwhelmed or underwhelmed? Do they reflect real circumstances?.

\section{Mestranol}

Mestranol (MeEE2, Picture 2), whose chemical formula is $\mathrm{C}_{21} \mathrm{H}_{26} \mathrm{O}_{2}$ ap]nd molecular weight is 310.42 , is more persistent in environment and has greater resistance to biodegradation, compared to EE2 (URAIPONG et al., 2017; ADEEL et al., 2017). Its octanol/water partition coefficient ( $\left.K_{\text {ow }}\right)$ is 4.61 , while its solubility in water is $0.3 \mathrm{mg} / \mathrm{L}$ under $20 \cong \mathrm{C}$ (LAl et al., 2000). 


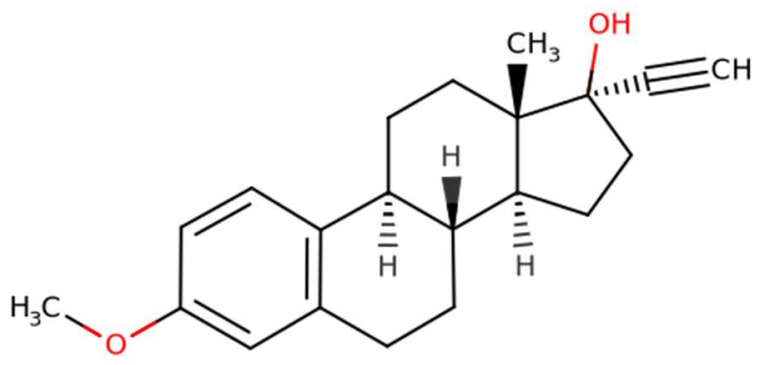

Picture 2: Mestranol.

Mestranol is a prodrug, consumed in its inactive form and converted to EE2 through biotransformation processes in mammal's livers (URAIPONG et al., 2017). The first hormonal pill, called Enovid $^{\circledR}$ was approved in 1960 in the United States. It had Mestranol $(150 \mu \mathrm{g})$ and Norethynodrel $(9.85 \mathrm{mg})$ in its composition. However, occurrence of side effects as nauseas, headaches and vomits motivated decrease in estrogen concentrations in pills (CHRISTIN-MAITRE, 2013). According to Food and Drug Administration's drugs data bank, smaller concentrations of MeEE2 and Norethynodrel in Enovid ${ }^{\circledR}$ reached $0.1 \mathrm{mg}$ and $2.5 \mathrm{mg}$, respectively. Nonetheless, pills commercialization was interrupted (FDA, 2019).

\section{Mestranol in aquatic ecosystems}

Systematic search for international studies concerning Mestranol presence in water resources led to 199 (ScienceDirect), 12 (PubMed) results. Search on Scielo did not have any result. As in $17 \alpha$-ethinylestradiol browse, studies done out of the determined period (1990-2019) as well as 'below limit detection' results were not considered. Thus, three articles were selected.

Table 4: Presence of Mestranol in aquatic ecosystems.

\begin{tabular}{|l|l|l|l|}
\hline COUNTRY & MATRIX & CONCENTRATION & AUTHORS \\
\hline \multirow{2}{*}{ Brazil } & Sediment & $801.6 \pm 20.6$ & MORAIS et al. (2019) \\
\cline { 2 - 4 } & Sediment & $119.24-301.99$ & SANTOS et al. (2019) \\
\hline Serbia & Sediment & $1.0 \pm 0.1-77.5 \pm 6.3$ & BUJAGIC et al. (2019) \\
\hline
\end{tabular}

Concentration in sediment $(\mathrm{ng} / \mathrm{g})$.

Two studies from Brazil reveal higher values of Mestranol in estuaries, compared to a Serbian investigation. The small number of identified articles can be interpreted as an indication that few inspections of MeEE2 in environment are made and/or this contaminant is less detected, which contrasts with $17 \alpha-$ ethinylestradiol. Additionally, it is possible that the key words or platforms used in this review were not adequate for Mestranol studies inquiry.

Analyzing two Brazilian academic studies, a dissertation and a thesis, we can observe high values of MeEE2 as well. Morais (2018) identified the contaminant ranging from 53.65 to $1960.98 \mathrm{ng} / \mathrm{g}$ in Jaguaribe River sediment, while Lima (2016) detected MeEE2 in another river, yet in the same Brazilian state. Acaraú River and Estuary had from 2.77 to $251.67 \mathrm{ng} / \mathrm{g}$ of Mestranol. Those studies are not in Table 3 because they were not identified through the systematic review, but previous literary investigation done by the authors. 


\section{Effects of Mestranol on biota}

It is important to emphasize that studies concerning the effects of oral contraceptives were not considered for this review, since they contain more than one chemical. Moreover, studies about MeEE2 effects on drugs pharmacokinetics were disregarded either. Hence, systematic search for Mestranol effects on biota led to 228 (ScienceDirect) and 141 (PubMed) results, in which seven appropriate articles were selected.

Most of the studies found were toxicological tests done in the 1990s, with varied doses concentrations. Abas et al. (1994) highlight that administrated doses in rats are higher than Mestranol concentrations ingested by women who consumed Enovid. Still, it is crucial to remind the differences between long-term and short-term effects as ecotoxicological tests can indicate either acute or chronic effects. Clinical studies might be more efficient in demonstrating chronic effects of pharmaceutical consumed by patients or people from a certain sample frame.

Table 5: Effects of Mestranol on biota.

\begin{tabular}{|l|l|l|l|}
\hline TEST ORGANISM & C & REPORTED EFFECTS & A \\
\hline Rabbits & $1.5 \mathrm{mg}$ & Portal fibrosis with biliary ploriferation & SKAJAERLUND (1994) \\
\hline \multirow{3}{*}{ Rats } & $112 \mu \mathrm{g} / \mathrm{kg}$ of feed & Higher arterial pressure & ABAS et al., (1994) \\
\cline { 2 - 4 } & $0.2 \mathrm{mg} / \mathrm{kg}$ diet & $\begin{array}{l}\text { Increase in percentage of liver occupied by Altered Hepatic } \\
\text { Foci (AHF) expressing Placental Glutathione S- Transferase } \\
\text { (PGST) }\end{array}$ & DRAGAN et al., (1996) \\
\cline { 2 - 5 } & $0.2 \mathrm{ppm}$ & $\begin{array}{l}\text { Increase in the amount of diploid hepatocytes (evidence of } \\
\text { carcinogeny) }\end{array}$ & DRAGAN et al. (1998) \\
\cline { 2 - 5 } & $\begin{array}{l}0.5 \mathrm{to} 10 \mathrm{mg} / \mathrm{kg} \\
\text { of body weight }\end{array}$ & Increase in the expression of splenic-macrophage FcyRs & GOMES et al. (2001) \\
\hline $\begin{array}{l}\text { Female } \\
\text { Hepatocytes }\end{array}$ & $3 \mu \mathrm{M}$ & Co-mitogenic effects & NI et al., (1994) \\
\hline $\begin{array}{l}\text { Mytillus } \\
\text { galloprovincialis }\end{array}$ & $0.1 \mu \mathrm{M}$ & Increase in lysosomal enzyme release & CANESI et al. (2007) \\
\hline $\begin{array}{l}\text { Salmonella } \\
\text { typhimurium }\end{array}$ & $1-10 \mathrm{mg} / \mathrm{dish}$ \\
\hline $\begin{array}{l}\text { Human } \\
\text { lymphocytes }\end{array}$ & $1-100 \mu \mathrm{m} / \mathrm{ml}$ & $\begin{array}{l}\text { Inhibition of bacterial growth and stimulation of chromatid } \\
\text { sisters sisters }\end{array}$ & DHILLON et al. (1994) \\
\hline
\end{tabular}

$\mathrm{C}=$ Concentration/ $\mathrm{A}=$ Author $(\mathrm{s})$

\section{Diethylstilbestrol}

Diethylstilbestrol (DES) (Picture 3) is a pharmaceutical compound whose chemical formula is $\mathrm{C}_{18} \mathrm{H}_{20} \mathrm{O}_{2}$ and octanol/water partition coefficient ( $\left.\mathrm{K}_{\mathrm{ow}}\right)$ is 5.07 . It is hydrophobic and its solubility in water is $12 \mathrm{mg} / \mathrm{L}$, under $20 \stackrel{\circ}{\circ}$.<smiles>CCC(=C(CC)c1ccc(O)cc1)c1ccc(O)cc1</smiles>

Picture 3: Diethylstilbestrol. 
Diethylstilbestrol was synthetized in 1938, when it was widely used as an oral estrogen due to its affinity with estrogen receptors. DES was prescribed to pregnant women from 1940 to 1971 with the aim of preventing miscarriage and other complications during pregnancy (LOOSE et al., 2010). Women, via pills without standardized doses, injections, suppositories and creams, globally ingested that pharmaceutical (JISHI et al., 2017). Nowadays, it is known that women who were exposed to DES present higher risks to have subfertility, premature menopause and pregnancy complications. Furthermore, the daughters of those women have more chances to acquire adenocarcinoma than the ones whose mothers were not exposed to Diethylstilbestrol (BJORKMAN et al., 2018). Approximately five to ten millions of American women either consumed DES during pregnancy or were exposed to it in the uterus (GIUSTI et al., 1995).

Moreover, Diethylstilbestrol was used to increase livestock weight in the 1950s and for poultry castration in the 1970s (MCLACHLAN, 2016). It is still used in cattle raising and aquiculture in many parts of the world (ADEDEJI et al., 2012). In spite of its prohibition in some countries, DES remains in society, even in daily products as milk (WEI et al., 2018).

\section{Diethylstilbestrol in aquatic ecosystems}

Systematic search concerning Diethylstilbestrol presence in water bodies lead to 400 (ScienceDirect), 7 (PubMed) and 21 (Scielo) results, in which 12 articles were selected. The studies selected are most from China (8 papers), followed by Brazil (2), Italy (1) and Spain (1).

Table 6: Presence of Diethylstilbestrol in aquatic ecosystems.

\begin{tabular}{|c|c|c|c|}
\hline COUNTRY & MATRIX & CONCENTRATION & AUTHORS \\
\hline \multirow{2}{*}{ Brazil } & Sediment & $304.07 \pm 15.54$ & MORAIS et al. (2019) \\
\hline & Sediment & $11.85-207.38$ & SANTOS et al. (2019) \\
\hline \multirow{12}{*}{ China } & Water & ND -8.51 & \multirow{2}{*}{ LEl et al. (2009) } \\
\hline & Sediment & ND - 4.51 & \\
\hline & Sediment & $1.25 \pm 0.17-8.79 \pm 1.28$ & ZHANG (2009) \\
\hline & Water & $N D-10$ & \multirow{3}{*}{ JIN et al. (2013) } \\
\hline & Sediment & ND -6 & \\
\hline & Suspended particles & $N D-6$ & \\
\hline & Water & $N D-2.15$ & RAO et al. (2013) \\
\hline & Water & 5.65 & LIU et al. (2017) \\
\hline & Water & $0.72-2.01$ & \multirow{2}{*}{ WANG et al. (2017b) } \\
\hline & Sediment & $1.53-3.57$ & \\
\hline & Water & ND - 9.6 & LUO et al. (2019) \\
\hline & Water & 12.05 & XU et al. (2019) \\
\hline Italy & Sediment & ND -63 & POJANA et al. (2007) \\
\hline Spain & Sediment & ND -0.32 & GORGA et al. (2015) \\
\hline
\end{tabular}

Concentration in water (ng/L), sediment and suspended particles (ng/g). ND = not detected.

Similar to investigations about $17 \alpha$-ethinylestradiol and Mestranol, the highest concentrations are observed in Brazilian aquatic ecosystems, which can be related to the sewage treatment methods adopted in Brazil and weather the activities responsible for the estrogen discharges are more intense in Brazilian territory than others.

\section{Effects of Diethylstilbestrol on biota}

Browse for studies about Diethylstilbestrol effects on organisms resulted in 181 (ScienceDirect), 12 
(PubMed) and 21 (Scielo) articles, but only 15 were adequate for this review.

Table 7: Effects of Diethylstilbestrol in biota.

\begin{tabular}{|c|c|c|c|}
\hline TEST ORGANISM & C & REPORTED EFFECTS & A \\
\hline Uca pugilator & $5 \mathrm{mg} / \mathrm{L}$ & Decrease in enzyme activity (cytobiase) & ZOU et al. (1999) \\
\hline $\begin{array}{l}\text { Ictalurus punctatus } \\
\text { hepatocytes }\end{array}$ & $\begin{array}{l}\text { From } 10 \mathrm{pM} \\
\text { to } \\
100 \mathrm{nM}\end{array}$ & Increase in VTG production & MONTEVERDI et al. (1999) \\
\hline Caenorhabditis elegans & $0.5 \mathrm{mg} / \mathrm{L}$ & Gene induction & REICHERT et al. (2005) \\
\hline \multirow{3}{*}{ Daphnia magna } & $0.5 \mathrm{mg} / \mathrm{L}$ & Decrease in fecundity & BRENNAN et al. (2006) \\
\hline & $500 \mu \mathrm{g} / \mathrm{L}$ & $\begin{array}{l}\text { Decrease in fecundity, ecdysis frequency and } \\
\text { metabolic changes of steroids }\end{array}$ & CLUBBS et al. (2007) \\
\hline & $100 \mu \mathrm{g} / \mathrm{L}$ & Growth inhibition & KASHIAN et al. (2004) \\
\hline Carassius auratus & $10 \mu \mathrm{g} / \mathrm{L}$ & $\begin{array}{l}\text { Increase in estrone and estradiol levels, decrease in } \\
\text { androgenic levels }\end{array}$ & YANG et al. (2008) \\
\hline Rats & $0.05 \mu \mathrm{g} / \mathrm{kg}$ & Chromosomal mutation & FUCIC et al. (2009) \\
\hline Anodonta cygnea & $0.75 \mu \mathrm{M}$ & Inhibition of ion exchange in epithelial mantle & ALVES et al. (2013) \\
\hline Oreochromis niloticus & $\begin{array}{l}100- \\
400 \mathrm{mg} / \mathrm{kg}\end{array}$ & $\begin{array}{l}\text { Mortality, feminization and } \\
\text { Decrease in growth and GSI }\end{array}$ & $\begin{array}{l}\text { MARÍN-RAMÍREZ et al. } \\
(2016)\end{array}$ \\
\hline Oryzias latipes & $\begin{array}{l}10- \\
1000 \mathrm{ng} / \mathrm{L}\end{array}$ & $\begin{array}{l}\text { Increase in mortality, incubation time and GSI; } \\
\text { abdominal swelling }\end{array}$ & LEl et al. (2016) \\
\hline
\end{tabular}

$\mathrm{C}=$ Concentration $/ \mathrm{A}=$ Author $(\mathrm{s})$

It is possible to observe a greater diversity of animals tested for Diethylstilbestrol than Mestranol. Besides a study involving rats, another one with human cells and at last a nematode experiment, all ecotoxicological tests were held with aquatic organisms, which includes fish, crabs, plankton and mussels.

\section{Dienestrol}

Dienestrol (Picture 4) (DNS) is a product of DES dehydrogenation. It was previously used to treat vaginal atrophy in women after menopause period (SCHREIBER et al., 2019). Its chemical formula is $\mathrm{C}_{18} \mathrm{H}_{18} \mathrm{O}_{2}$, its solubility in water is $3 \mathrm{mg} / \mathrm{L}$ under 37 ㅇ C and its Log Kow is 5.64 (YUAN et al., 2015).<smiles>CC=CC(=CC)c1ccc(O)cc1</smiles>

Picture 4: Dienestrol.

\section{Dienestrol in aquatic ecosystems}

Most of the papers found during this review were analysis of Dienestrol in dairy products and studies of chemical methods to detect it. Additionally, papers concerning DNS presence in animals were not considered. Therefore, the review about Dienestrol occurrence in water bodies lead to one (Scielo), 162 (ScienceDirect) and 119 (PubMed) results, in which one article was selected. A Brazilian paper evaluated DNS presence in a mangrove-estuary environment. Its concentration in sediment varied from not detected to $56.17 \mathrm{ng} / \mathrm{g}$ (SANTOS et al., 2019). 
The small amount of studies about Dienestrol can be interpreted as a consequence of it being a product of Diethylstilbestrol, which is more investigated. It is noticeable that DNS investigations are recent ones, if we consider the identified papers cited on the following section too.

\section{Effects of Dienestrol on biota}

Screening for papers about Dienestrol effects on organisms resulted in one (Scielo), 283 (ScienceDirect) and 119 studies on PubMed. However, four studies were considered appropriate for this review.

Table 8: Effects of Dienestrol.

\begin{tabular}{|l|l|l|l|}
\hline $\begin{array}{l}\text { TEST } \\
\text { ORGANISM }\end{array}$ & C & REPORTED EFFECTS & A \\
\hline \multirow{3}{*}{ Rats } & $\begin{array}{l}0,0037 ; 0,037 \text { and } 0,37 \\
\mathrm{mg} / \mathrm{kg} / \mathrm{day}\end{array}$ & Testicular atrophy & FROEHNER et al. (2012) \\
\cline { 2 - 4 } & 50 and $3,12 \mu \mathrm{g} / \mathrm{kg} / \mathrm{day}$ & $\begin{array}{l}\text { Abortion and decrease in sperm progressive } \\
\text { molility }\end{array}$ & SCHREIBER et al. (2019) \\
\cline { 2 - 4 } & 75 and $50 \mu \mathrm{gg}$ bw/day & Abortion & GONZÁLEZ et al. (2018) \\
\hline Yeast cells & $10 \mu \mathrm{M}-156 \mathrm{nM}$ & $\begin{array}{l}\text { Constitutive Androstane Receptor (CAR) } \\
\text { agonistic effect }\end{array}$ & KAMATA et al. (2018) \\
\hline
\end{tabular}

$\mathrm{C}=$ Concentration $/ \mathrm{A}=$ Author $(\mathrm{s})$

Rats and yeast cells resistance to the estrogen was analyzed. Rats from different studies (SCHREIBER et al., 2019; GONZALEZ et al., 2018) had one common reported effect, which is abortion, as a common concentration of $50 \mu \mathrm{g} / \mathrm{kg} / \mathrm{day}$. We would like to highlight a detected study that reports the incidence of mammal tumors in rats (INANO et al., 1993). Nonetheless, we did not considered it because the paper does not specify the dose concentration administrated. Moreover, epithelial cysts smaller than $1.5 \mathrm{~mm}$ were observed rats treated with $15 \mathrm{mg}$ of Dienestrol dissolved in sterile water 1.3 and $1.7 \mathrm{ml}$ for five to seven months (SILVA et al., 1998).

\section{An overall view}

Considering the review concerning 17 $\alpha$-ethinylestradiol, Mestranol, Diethylstilbestrol and Dienestrol, some aspects of our current knowledge about synthetic estrogens can be discussed. According to systematic investigation, held through 62 papers collected in ScienceDirect, PubMed and Scielo, most studies were developed by scientists located in China (21), followed by The United States (10) and Brazil (8).

European studies were mainly developed by Spain (4), Italy (3) and Poland (2). The United Kingdom, Austria, Germany, Croatia, Scotland, Portugal, Mexico, Japan, Malaysia, India and Canada had one paper each. There were three studies whose research teams were composed by scientists with different affiliations. Those partnerships were between Spain and Italy; Brazil and Mexico; Sweden and The United States. Developed countries are majorly present in the rank, which is expected, considering the high cost of emerging contaminants analysis and the fact that investment in Science is not equal around the globe.

Moreover, despite endocrine disrupting chemicals being a raising topic, it might not be seen as a priority to countries that are still dealing with challenges that are more basic. Nevertheless, one Latin 
American country stands out for having contributed to more studies than it would be predicted by stereotypes. Brazilian papers were published from 2011 to 2019 (half of them in 2019), which can be seen as a prospecting period for its scientific community. After all, studies about synthetic hormones are recent since that topic is an emerging one. The Graphic 2 shows the distribution of the papers browsed along the years.

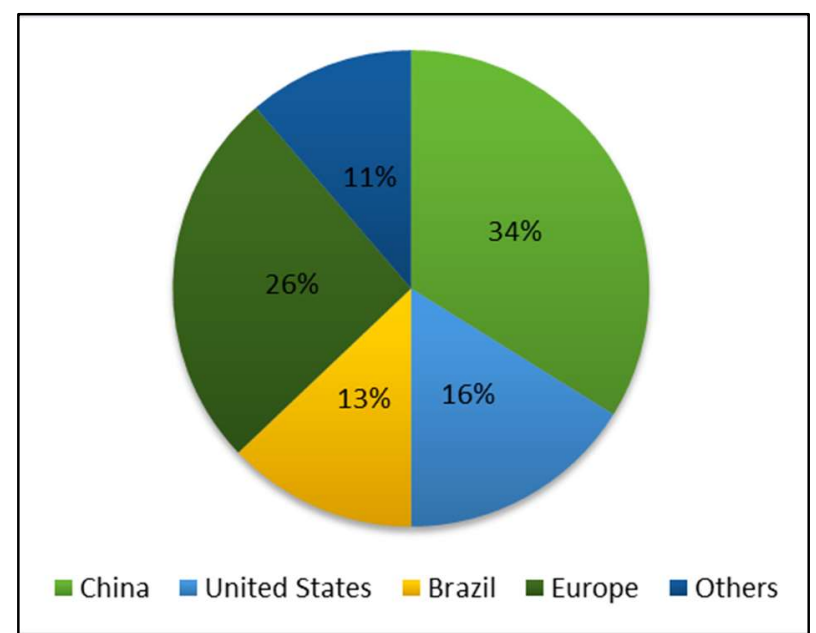

Graphic 1: Countries representativeness on reviewed studies.

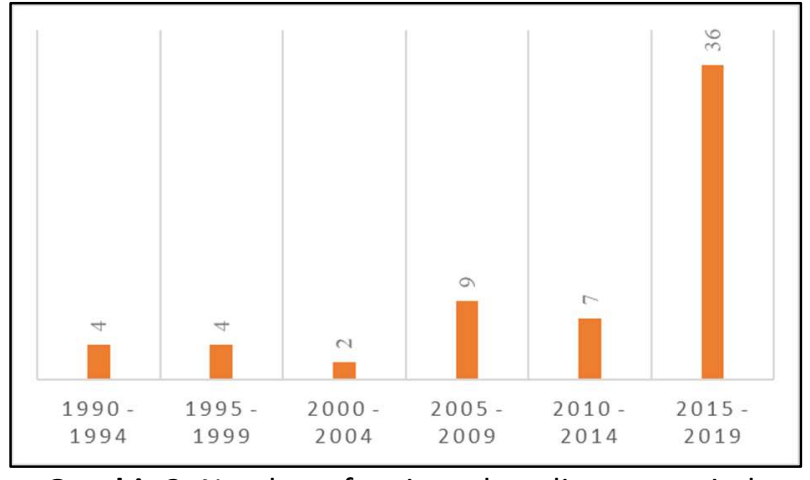

Graphic 2: Number of reviewed studies per period.

It is possible to observe that most of the papers investigated were published from 2015 to 2019, corresponding to 36 papers. This shows that although endocrine disruptors are a discussed theme since the 1990s, the world seems to be still crawling towards a complete understanding of synthetic estrogens as a concrete environmental problem.

\section{CONCLUSIONS}

Synthetic estrogens are important study objects, whose investigation can be divergent. The superiority of contaminants as $17 \alpha$-ethinylestradiol and Diethylstilbestrol, in quantitative terms, could be observed since they were more investigated than their metabolites. Secondly, the relevance of China, United States and Brazil to research about the compounds is clear.

Finally, the highest concentrations of the contaminants were majorly in Brazilian waters, which reveals not only insufficient methods of effluents treatment, but also the need of implementation of more effective ones. Effects observed in organisms exposed are varied and concerning. Furthermore, the repercussion of ecotoxicological tests results was also questioned, once the doses administrated can be incompatible to real levels. Therefore, it is necessary to consider the complexity of interactions between the xenobiotic and wildlife.

Hence, to discuss Environmental Pollution as Environmental Science is to evaluate economic, social, natural and political backgrounds. Synthetic estrogens have gained recognition as prospective concerns for the current and future generations. They started to be studied in the previous decades, but they are not entirely dealt with in practical terms. Their ubiquitous presence seems to be invisible to people outside of Academia. Scientific community's role might be knowledge creation. However, what comes next? Managers 
of natural resources as citizens must be aware of emerging issues, which requires wide and equal scientific divulgation. Consequently, true commitment to solving emerging challenges should not be faced as an option, but as a duty.

ACKNOWLEDGEMENTS: The authors are thankful to Universidade Federal do Ceará for the support to access the restricted papers investigated in this review.

\section{REFERENCES}

ABAS, N.; KOIVUNEN, D. G.; JOHNSON, J. A.. Pressor responsiveness in rats with hypertension induced by mestranol. Contraception, Los Altos, v.50, n.4, p.383-389, 1994. DOI: https://doi.org/10.1016/0010-7824(94)90025-6

ADEDEJI, O. B.; DURHAN, E. J.; GARCIA-REYERO, N.; KAHL, M. D.; JENSEN, K. M.; LALONE, C. A.; MAKYNEN, E. A.; PERKINS, E. J.; THOMAS, L.; VILLENEUVE, D. L.; ANKLEY, G. T.. ShortTerm Study Investigating the Estrogenic Potency of Diethylstilbesterol in the Fathead Minnow (Pimephales promelas). Environmental Science \& Technology, Easton, v.46, n.14, p.7826-7835, 2012. DOI: https://doi.org/10.1021/es301043b

ADEEL, M.; SONG, X.; WANG, Y.; FRANCIS, D.; YANG, Y.. Environmental impact of estrogens on human, animal and plant life: a critical review. Environment International, Elmsford, v.99, n.1, p.107-119, 2017. DOI: https://doi.org/10.1016/j.envint.2016.12.010

ALBERO, B.; SÁNCHEZ-BRUNETE, C.; MIGUEL, E.; PÉREZ, R. A.; TADEO, J. L.. Anaysis of natural-occurring and synthetic sexual hormones in sludge-amended soils by matrix solidphase dispersion and isotope dilution gas chromatographytandem mass spectrometry. Journal of Chromatography A, New York, v.1283, n.1, p.39-45, 2013. Dol: https://doi.org/10.1016/j.chroma.2013.01.113

ALVES, M. G.; OLIVEIRA, P. F.. Effects of non-steroidal estrogen diethylstilbestrol on $\mathrm{pH}$ and ion transport in the mantle epithelium of a bivalve Anodonta cygnea.

Ecotoxicology and Environmental Safety, New York, v.97, n.1, p.230-235, 2013. DOI:

https://doi.org/10.1016/j.ecoenv.2013.07.024

ANNAMALAI, J.; NAMASIVAYAN, V.. Endocrine disrupting chemicals in the atmosphere: Their effects on humans and wildlife. Environment International, Elmsford, v.76, n.1, p.78-97, 2015. DOI:

https://doi.org/10.1016/j.envint.2014.12.006

ARIS, A. Z.; SHAMSUDDIN, A. S.; PRAVEENA, S. M. Occurrence of $17 \alpha$-ethynylestradiol (EE2) in the environment and effect on exposed biota: a review. Environment International, New York, v.69, n.1, p.104-119, 2014. DOI: https://doi.org/10.1016/j.envint.2014.04.011

ARMSTRONG, B. M.; LAZORCHAK, J. M.; JENSEN, K. M.; HARING, H. J.; SMITH, M. E.; FLICK, R. W.; BENCIC, D. C.; BIALES, E. D.. Reproductive effects in fathead minnows (Pimphales promelas) following a $21 \mathrm{~d}$ exposure to $17 \alpha-$ ethinylestradiol. Chemosphere, Oxford, v.144, n.1, p.366373, 2016. DOI: https://doi.org/10.1016/j.chemosphere.2015.08.078

ASHFAQ, M.; SUN, Q.; MA, C.; RASHID, A.; LI, Y.; MULLA, S. I.; $Y U, C$.. Occurrence, seasonal variation and risk evaluation of selected endocrine disrupting compounds and their transformation products in Jiulong river and estuary, China. Marine Pollution Bulletin, Oxford, v.145, n.1, p. 370-376, 2019. DOI: https://doi.org/10.1016/j.marpolbul.2019.05.016

AUTRUP, H.; BARILE, F. A.; BERRY, S. C.; BLAAUBOER, B. J.; BOOBIS, A.; BOLT, H.; BORGET, C. J.; DEKANT, H.; DIETRICH, D.; DOMINGO, J. L.; GORI, G. B.; GREIM, H.; HENGSTLEIR, J.; KACEW, S.; MARQUARDT, H.; PELKONEN, O.; SAVOLAINEN, K.; HESLOP-HARRISON, P.; VERMEULEN, N. P.. Human exposure to synthetic endocrine disrupting chemicals (SEDCs) is generally negligible as compared to natural compounds with higher or comparable endocrine activity. How to evaluate the risk of the S-EDCs?. Computational Toxicology, Amsterdam, v.14, n.1, p.1-6, 2020. DOI: https://doi.org/10.1016/j.comtox.2020.100124

BAIRD, C.; CANN, M.. Environmental Chemistry. 4. ed. New York: W. H. Freeman, 2008.

BERTIN, A.; DAMIENS, G.; CASTILLO, D.; FIGUEROA, R.; MINIER, C.; GOUIN, N.. Developmental instability is associated with estrogenic endocrine disruption in the Chilean native fish species, Trichomycterus areolatus. Science of the Total Environment, Amsterdam, v.714, n.1, p.1-10, 2020. DOI:

https://doi.org/10.1016/j.scitotenv.2020.136638

BHANDARI, R. K.; DEEM, S. L.; HOLLIDAY, D. K.; JANDEGIAN, C. M.; KASSOTIS, C. D.; NAGEL, S. C.; TILLITT, D. E.; VOM SAAL, F. S.; ROSENFELD, C. S.. Effects of the environmental estrogenic contaminants bisphenol $A$ and $17 \alpha$-ethinyl estradiol on sexual development and adult behaviors in aquatic wildlife species. General and Comparative Endocrinology, New York, v.214, n.1, p.195-219, 2015. DOI: https://doi.org/10.1016/j.ygcen.2014.09.014

BJORKMAN, S.; TAYLOR, H. S.. Diethylstilbestrol (DES). Encyclopedia of Reproduction, Amsterdam, v.2, n.1, p.760766, 2018. DOI: https://doi.org/10.1016/B978-0-12-8012383.64417-3

BOVIER, T. F.; ROSSI, S.; MITA, D. G.; DIGILIO, F. A.. Effects of the synthetic estrogen $17-\alpha$-ethinylestradiol on Drosophila melanogaster: Dose and gender dependence. Ecotoxicology and Environmental Safety, New York, v.162, n.1, p.625-632, 2018. DOI: https://doi.org/10.1016/i.ecoenv.2018.07.020

BRENNAN, S. J.; BROUGHAM, C. A.; ROCHE, J. J.; FOGARTY, 
A. M.. Multigenerational effects of four selected environmental oestrogens on Daphnia magna. Chemosphere, Oxford, v.64, n.1, p.49-55, 2006. DOI: https://doi.org/10.1016/j.chemosphere.2005.11.046

BREVES, J. P.; DUFFY, T. A.; EINARDOTTIR, I. E.; BJORNSSON, B. T.; McCORMICK, S. D.. Effects of the synthetic estrogen 17- $\alpha$-ethinylestradiol on Drosophila melanogaster: Dose and gender dependence. Aquatic Toxicology, Amsterdam, v.203, n.1, p.28-39, 2018. DOI: https://doi.org/10.1016/j.aquatox.2018.07.018

BUJAGIC, I. M.; GRUJIC, S.; LAUSEVIC, M.; HOFMANN, T.; $\mathrm{MICIC}, \mathrm{V}$.. Emerging contaminants in sediment core from the Iron Gate I Reservoir on the Danube River. Science of Total Environment, Amsterdam, v.662, n.1, p.77-87, 2019. DOI: https://doi.org/10.1016/j.scitotenv.2019.01.205

CANESI, L.; LORUSSO, L. C.; CIACCI, C.; BETTI, M.; ROCCHI, M.; POJANA, G.; MARCOMINI, A.. Immunomodulation of Mytilus hemocytes by individual estrogenic chemicals and environmentally relevant mixtures of estrogens: In vitro and in vivo studies. Aquatic Toxicology, Amsterdam, v.81, n.1, p.36-44, 2007. DOI:

https://doi.org/10.1016/j.aquatox.2006.10.010

CAPOLUPO, M.; DÍAZ-GARDUÑO, B.; MARTÍN-DÍAZ, M. L.. The impact of propranolol, $17 \alpha$-ethinylestradiol, and gemfibrozil on early life stages of marine organisms: effects and risk assessment. Environmental Science and Pollution Research International, Cham, v.25, n.1, p.32196-32209, 2018. DOI: http://doi.org/10.1007/s11356-018-3185-6

CHEN, T.; HSIEH, C.. Fighting Nemo: Effect of $17 \alpha-$ ethinylestradiol (EE2) on aggressive behavior and social hierarchy of the false clown anemonefish Amphiprion ocellaris. Marine Pollution Bulletin, Oxford, v.124, n.1, p.760-766, 2018. DOI:

https://doi.org/10.1016/j.marpolbul.2016.12.042

CHRISTIN-MAITRE, S.. History of oral contraceptive drugs and their use worldwide. Best Practice \& Research Clinical Endocrinology \& Metabolism, Amsterdam, v.27, n.1, p.3-12, 2013. DOI: https://doi.org/10.1016/j.beem.2012.11.004

CLUBBS, R. L.; BROOKS, B. W.. Daphnia magna responses to a vertebrate estrogen receptor agonist and an antagonist: $A$ multigenerational study. Ecotoxicology and Environmental Safety, New York, v.67, n.1, p.385-398, 2007. DOI: https://doi.org/10.1016/j.ecoenv.2007.01.009

CZARNY, K.; SZCZUKOCKI, D.; KRAWCZYK, B.; SKRZYPEK, S.; ZIELINSKI, M.; GADZALA-KOPCIUCH, R.. Toxic effects of single animal hormones and their mixtures on the growth of Chlorella vulgaris and Scenedesmus armatus. Chemosphere, Oxford, v.224, n.1, p.93-102, 2019. DOI: https://doi.org/10.1016/i.chemosphere.2019.02.072

DAMKJAER, K.; WEISSER, J. J.; MSIGALA, S. C.; MDEGELA, R.; STYRISHAVE, B.. Occurrence, removal and risk assessment of steroid hormones in two wastewater stabilization pond systems in Morogoro, Tanzania. Chemosphere, Oxford, v.212, n.1, p.1142-1154, 2018. DOI: https://doi.org/10.1016/i.chemosphere.2018.08.053

DHONT, M.. History of oral contraception.The European Journal of Contraception \& Reproductive Health Care,
London, v.15, n.2, p.12-18, 2010. DOI:

https://doi.org/10.3109/13625187.2010.513071

DHILLON, V. S.; SINGH, J. R.; SINGH, H.; KLER, R. S.. In vitro and in vivo genotoxicity evaluation of hormonal drugs v.mestranol. Mutation Research/ Genetic Toxicology, Amsterdam, v.322, n.3, p. 173-183, 1994. DOI: https://doi.org/10.1016/0165-1218(94)90004-3

DORABAWILA, N., GUPTA, G.. Endocrine disrupter: estradiol: in Chesapeake Bay tributaries. Journal of Hazardous Materials, Amsterdam, v.120, n.1-3, p. 67-71, 2005. DOI: https://doi.org/10.1016/j.jhazmat.2004.12.031

DRAGAN, Y. P.; SHIMEL, R. J.; BAHNUB, L.; SATTLER, G.; VAUGHAN, J. R.; JORDAN, V. C.; PITOT, H. C.. Effect of chronic administration of mestranol, tamoxifen, and toremifene on hepatic ploidy in rats. Toxicological Sciences, Orlando, v.43, n.2, p.129-138, 1998. DOI: http://doi.org/10.1006/toxs.1998.2464

DRAGAN, Y. P.; SINGH, J.; PITOT, H. C.. Effect of the separate and combined administration of mestranol and phenobarbital on the development of altered hepatic foci expressing placental form of glutathione S-transferase in rats. Carcinogenesis, Oxford, v.17, n.9, p.2043-2052, 1996. DOI: http://doi.org/10.1093/carcin/17.9.2043

DUSSAULT, E. B.; BALAKRISHNAN, V. K.; SVERKO, E.; SOLOMON, K. R.; SIBLEY, P. K.. Toxicity of human pharmaceuticals and personal care products to benthic invertebrates. Environmental Toxicology and Chemistry, Hoboken, v.27, n.2, p.425-432, 2008. DOI: http://doi.org/10.1897/07-354R.1

EC. European Commission. European Workshop on the Impact of Endocrine Disrupters on Human Health and Wildlife. Weybridge: European Commission, 1996.

FERREIRA, A. P.. Endocrine disruptors in sludge wastewater treatment plants: environmental complications. Acta Scientiarum Technology, Maringá, v.35, n.2, p.307-316, 2013. DOI:

http://doi.org/10.4025/actascitechnol.v35i2.10619

FISHER, J. S.; TURNER, K. J.; BROWN, D.; SHARPE, R. M.. Effect of neonatal exposure to estrogenic compounds on development of the excurrent ducts of the rat testis through puberty to adulthood. Environmental Health Perspectives, Research Triangle Park, v.107, n.5, p.397-405, 1999. DOI: http://doi.org/10.1289/ehp.99107397

FROEHNER, S.; MACHADO, K. S.; STEFAN, E.; BLENINGER, T.; ROSA, E. C.; MARTINS, C. C.. Occurrence of selected estrogens in mangrove sediments. Marine Pollution Bulletin, Oxford, v.64, n.1, p.75-79, 2012. Dol: https://doi.org/10.1016/i.marpolbul.2011.10.021

FUCIC, A.; STOJKOVIC, R.; KATIC, J.; MARKOVIC, D.; FERENCIC, Z.; KORSIC, M.; JAZBEC, A. M.; GAMULIN, M.. Animal model for age- and sex-related genotoxicity of diethylstilbestrol. Brazilian Journal of Medical and Biological Research, Ribeirão Preto, v.42, n.11, p.1090-1096, 2009. DOI: https://doi.org/10.1590/S0100-879X2009001100015

GIUSTI, R. M.; IWAMOTO, K.; HATCH, E. E.. Diethylstilbestrol Revisited: A Review of the Long-Term Health Effects. Annals 
of Internal Medicine, Philadelphia, v.122, n.10, p.778-788, 1995. DOI: https://doi.org/10.7326/0003-4819-12210-199505150-00008

GOMES, F.; RUIZ, P.; BERNAL, J. A.; ESCOBAR, M.; GARCIAEGITO, A.; LOPEZ-SAEZ, J. J. B.. Enhancement of SplenicMacrophage Fcy Receptor Expression by Treatment with Estrogens. Clinical and Diagnostic Laboratory Immunology, Washington D.C., v.8, n.4, p.806-810. DOI: 10.1128/CDLI.8.4.806-810.2001

GONZÁLEZ, N.; SCHREIBER, E.; TORRENTE, M.; KUMAR, V.; DOMINGO, J. L.; GÓMEZ, M. M.. Assessment of reproductive toxicity of male rats through maternal exposure to dienestrol. Toxicology Letters, Amsterdam, v.295, n.1, p.69266, 2018. DOI:

https://doi.org/10.1016/j.toxlet.2018.06.701

GORGA, M.; INSA, S.; PETROVIC, M.; BARCELÓ, D.. Occurrence and spatial distribution of EDCs and related compounds in waters and sediments of Iberian rivers. Science of the Total Environment, Amsterdam, v.503-504, n.1, p.69-86, 2015. DOI:

https://doi.org/10.1016/i.scitotenv.2014.06.037

GOUNDADKAR, B. B.; KATTI, P.. Environmental estrogen(s) induced swimming behavioural alterations in adult zebrafish (Danio rerio). Environmental Toxicology and Pharmacology, Amsterdam, v.54, n.1, p.146-154, 2017. DOI: https://doi.org/10.1016/i.etap.2017.07.001

HAMPL, R.; KUBÁTOVÁ, J.; STÁRKA, L.. Steroids and endocrine disruptors - History, recent state of art and open questions. The Journal of Steroid Biochemistry and Molecular Biology, Amsterdam, v.155, n.2, p.217-223, 2016. DOI: https://doi.org/10.1016/j.jsbmb.2014.04.013.

HAMPSON, E.. A brief guide to the menstrual cycle and oral contraceptive use for researches in behavioral endocrinology. Hormones and Behavior, New York, v.119, n.1, p.1-8, 2020. DOI:

https://doi.org/10.1016/i.yhbeh.2019.104655

HE, K.; TIMM, A.; BLANEY, L.. Simultaneous determination of UV-filters and estrogens in aquatic invertebrates by modified quick, easy, cheap, effected, rugged, and safe extraction and liquid chromatography tandem mass spectrometry. Journal of Chromatography A, New York, v.1509, n.1, p.91-101, 2017. DOI: https://doi.org/10.1016/i.chroma.2017.06.039

HOGA, C. A.; ALMEIDA, F. L.; REYES, F. G. R.. A review on the use of hormones in fish farming: Analytical methods to determine their residues. CyTA - Journal of Food, v.16, n.1, p. 679-691, 2018. DOI:

https://doi.org/10.1080/19476337.2018.1475423

HUANG, B.; WANG, B.; REN, D.; JIN, W.; LIU, J.; PENG, J.. Occurrence, removal and bioaccumulation of steroid estrogens in Dianchi Lake catchment, China. Environment International, Elmsford, v.59, n.1, p.262-273, 2013. DOI: https://doi.org/10.1016/j.envint.2013.06.018

HUANG, Y.; XIE, X.; ZHOU, L. J.; JI, X.; GAO, B.; XU, G. Z.; LI, A.. Multi-phase distribution and risk assessment of endocrine disrupting chemicals in the surface water of the Shaying River, - Huai River Basin, China. Ecotoxicology and Environmental Safety, New York, v.173, n.1, p.45-53, 2019.
DOI: https://doi.org/10.1016/i.ecoenv.2019.02.016

IARC. International Agency for Research on Cancer. IARC Monographs on the Evaluation of Carcinogenic Risks to Humans: Hormonal Contraception and Post-menopausal Hormonal Therapy. Lyon: IARC, 1999.

INANO, H.; SUZUKI, K.; ISHII-OHBA, H.; YAMANOUCHI, H.; TAKAHASHI, M.; WAKABAYASHI, K.. Promotive effects of diethylstilbestrol, its metabolite (Z, Z-dienestrol) and a stereoisomer of the metabolite ( $\mathrm{E}, \mathrm{E}$-dienestrol) in tumorigenesis of rat mammary glands pregnancydependently initiated with radiation. Carcinogenesis, Oxford, v.14, n.10, p. 2157-2163, 1993. DOI: https://doi.org/10.1093/carcin/14.10.2157

IWANOWICZ, L. R.; BLAZER, V. S.; PINKNEY, A. E.; GUY, C. P.; MAJOR, A. M.; MUNNEY, K.; MIERZYKOWSKI, S.; LINGENFELSER, S.; SECORD, A.; PATNODE, K.; KUBIAK, T. J.; STERN, C.; HAHN, C. M.; IWANOWICZ, D. D.; WALSH, H. L.; SPERRY, A.. Evidence of estrogenic endocrine disruption in smallmouth and largemouth bass inhabiting Northeast U.S national wildlife refuge waters: A reconnaissance study. Ecotoxicology and Environmental Safety, New York, v.124, p.50-59, 2016. DOI: https://doi.org/10.1016/j.ecoenv.2015.09.035

JAVUREK, A. B.; SPOLLEN, W. G.; JOHNSON, S. A.; BIVENS, N. J.; BROMERT, K. H.; GIVAN, S. A.; ROSENFELD, C. S.. Effects of exposure to bisphenol $A$ and ethinyl estradiol on the gut microbiota of parents and their offspring in a rodent model. Gut microbes, Austin, v.7, n.6, p. 471-485, 2016. DOI: http://doi.org/10.1080/19490976.2016.1234657

JIN, S.; YANG, F.; XU, Y.; HEPING, D.; WEIPING, L.. Risk assessment of xenoestrogens in a typical domestic sewageholding lake in China. Chemosphere, Oxford, v.93, n.6, p.892-898, 2013. DOI:

https://doi.org/10.1016/i.chemosphere.2013.05.037

JISHI, T. A.; CONSOLATO, S.. Current perspective of diethylstilbestrol (DES) exposure in mothers and offspring. Reproductive Toxicology, Elmsford, v.71, v.1, p.71-77, 2017. DOI: https://doi.org/10.1016/j.reprotox.2017.04.009

KAMATA, R.; NAKAJIMA, D.; SHIRAISHI, F.. Agonistic effects of diverse xenobiotics on the constitutive androstane receptor as detected in a recombinant yeast-cell assay. Toxicology in Vitro, New York, v.46, p.335-349, 2018. DOI: https://doi.org/10.1016/i.tiv.2017.09.014.

KASHIAN, D. R.; DODSON, S. I.. Effects of vertebrate hormones on development and sex determination in Daphnia magna. Environmental Toxicology and Chemistry, Hoboken, v.23, n.5, p.1282-1288, 2004. DOI: 10.1897/03$\underline{372}$

KIYAMA, R.; WADA-KIYAMA, Y.. Estrogenic endocrine disruptors: Molecular mechanisms of action. Environment International, Elmsford, v.83, n.1, p.11-40, 2015. DOI: https://doi.org/10.1016/j.envint.2015.05.012

KOVACEVIC, V.; SIMPSON, A. J.; SIMPSON, M. J.. The concentration of dissolved organic matter impacts the metabolic response in Daphnia magna exposed to 17 aethynylestradiol and perfluorooctane sulfonate. Ecotoxicology and Environmental Safety, New York, v.170, 
n.1, p.468-478, 2019. DOI:

https://doi.org/10.1016/i.ecoenv.2018.12.008

LÁZARO-VELASCO, A.; ISIDRO-CRISTOBAL, H.; ALCÁNTARVÁZQUEZ, J. P.; ANTONIO-ESTRADA, C.; CALZADA-RUIZ, D.; TORRE, R. M.. Effect of the combination of a cold-water temperature and exogenous estrogens on feminization, growth, gonadosomatic index and fat muscle content of Nile tilapia Oreochromis niloticus (Linnaeus, 1758). Latin American Journal of Aquatic Research, Valparaíso, v.47, n.1, p.52-64, 2019. DOI: http://dx.doi.org/10.3856/vol47-issue1fulltext-7

LEI, B.; HUANG, S.; ZHOU, Y.; WANG, D.; WANG, Z.. Levels of six estrogens in water and sediment from three rivers in Tianjin area, China. Chemosphere, Oxford, v.76, n.1, p.3642, 2009. DOI:

https://doi.org/10.1016/i.chemosphere.2009.02.035

LEI, B.; PENG, W.; WEI, L.; YINGXIN, Y.; XU, J.; WANG, J.. Diethylstilbestrol at environmental levels affects the development of early life stage and target gene expression in Japanese medaka (Oryzias latipes). Ecotoxicology, London, v.25, n.3, p.563-573, 2016. DOI: http://doi.org/10.1007/s10646-016-1615-0

LI, J.; FU, J.; ZHANG, H.; LI, Z.; MA, Y.; WU, M.; LIU, X.. Spatial and seasonal variations of occurrences and concentrations of endocrine disrupting chemicals in unconfined and confined aquifers recharged by reclaimed water: A field study along the Chaobai River, Beijing. Science of Total Environment, Amsterdam, v.450-451, n.1-2, p.162-168, 2013. DOI: https://doi.org/10.1016/j.scitotenv.2013.01.089

LIMA, M. F. B.. Esteróis e disruptores endócrinos em sedimentos como indicadores da contaminação no rio Acaraú. Dissertação (Mestrado em Ciências Marinhas Tropicais) - Universidade Federal do Ceará, Fortaleza, 2016.

LIU, D.; WU, S.; XU, H.; ZHANG, Q.; ZHANG, S.; SHI, L.; YAO, C.; LIU, Y.; CHENG, J.. Distribution and bioaccumulation of endocrine disrupting chemicals in water, sediment and fishes in a shallow Chinese freshwater lake: Implications for ecological and human health risks. Ecotoxicology and Environmental Safety, New York, v.140, n.1, p.222-229, 2017. DOI: https://doi.org/10.1016/i.ecoenv.2017.02.045

LIU, J.; DAN, X.; LU, G.; SHEN, J.; WU, D.; YAN, Z.. Investigation of pharmaceutically active compounds in an urban receiving water: Occurrence, fate and environmental risk assessment. Ecotoxicology and Environmental Safety, New York, v.154, n.1, p.214-220, 2018. DOI: https://doi.org/10.1016/j.ecoenv.2018.02.052

LIU, J.; LU, G.; XIE, Z.; ZHANG, Z.; LI, S.; YAN, Z.. Occurrence, bioaccumulation and risk assessment of lipophilic pharmaceutically active compounds in the downstream rivers of sewage treatment plants. Science of Total Environment, Amsterdam, v.511, n.1, p.54-62, 2015. DOI: https://doi.org/10.1016/j.scitotenv.2014.12.033

LIU, Y.; SU, W.; ZHU, Y.; XIAO, L.; HU, T.. Endocrine disrupting compounds in the middle and lower reaches of the Lhasa River Basin: Occurrence, distribution, and risk assessment. Science of the Total Environment, Amsterdam, v.727, n.1, p.1-9, 2020. DOI: https://doi.org/10.1016/j.scitotenv.2020.138694
LOOSE, D. S.; STANCEL, G. M.. Estrogênios e progestogênios. In: GOODMAN, L. S.; GILMAN, A.. As Bases Farmacológicas da Terapêutica. 11 ed. Porto alegre: AMGH, 2010.

LUCENA, W. S.. O fármaco 17a-etinilestradiol: seus possíveis efeitos à saúde humana e animal por exposições ambientais. Monografia (Especialização em Tecnologias Industriais Farmacêuticas) - Fundação Oswaldo Cruz, Rio de Janeiro, 2013.

LUO, Z.; TU, Y.; LI, H.; QIO, B.; LIU, Y.; YANG, Z.. Endocrinedisrupting compounds in the Xiangjiang River of China: Spatial-temporal distribution, source apportionment, and risk assessment. Ecotoxicology and Environmental Safety, New York, v.167, n.1, p.476-484, 2019. DOI: https://doi.org/10.1016/j.ecoenv.2018.10.053

MARÍN-RAMÍREZ, J. A.; ALCÁNTAR-VÁZQUEZ, J. P.; ANTONIO-ESTRADA, C.; TORRE, R. M.; CALZADA-RUIZ, D.. Feminization of nile tilapia Oreochromis niloticus (L.) by diethylstilbestrol growth and gonadosomatic index. Ecosistemas y recursos agropecuários, Villahermosa, v.3, n.7, p.51-61, 2016. DOI: http://doi.org/10.19136/era.a3n7.78

MCLACHLAN, J. A.. Environmental signaling: from environmental estrogens to endocrine- disrupting chemicals and beyond. Andrology, Hoboken, v.4, n.4, p.684-694, 2016. DOI: 10.1111/andr.12206

MITCHELMORE, C. L.; HE, K.; GONSIOR, M.; HAIN, E.; HEYES, A.; CLARK, C.; YOUNGER, R.; SCHMITT-KOPPLIN, P.; FEERICK, A.; CONWAY, A.; BLANEY, L.. Science of the Total Environment, Amsterdam, v.670, p.398-410, 2019. DOI: https://doi.org/10.1016/j.scitotenv.2019.03.034

MONTAGNER, C. C.; JARDIM, W. F.. Spatial and seasonal variations of pharmaceuticals and endocrine disruptors in the Atibaia River, São Paulo State (Brazil). Journal of the Brazilian Chemical Society, São Paulo, v.22, n.8, p.14521462, 2011. DOI: https://doi.org/10.1590/S0103$\underline{50532011000800008}$

MONTEVERDI, G. H.; DI GIULIO, R. T.. An enzyme-linked immunosorbent assay for estrogenicity using primary hepatocyte cultures from the channel catfish (Ictalurus punctatus). Archives of Environmental Contamination and Toxicology, New York, v.37, n.1, p. 62-69, 1999. DOI: http://doi.org/10.1007/s002449900490

MORAIS, P. C. V.. Distribuição espaço-temporal de esteróis e hormônios estrógenos e o seu potencial toxicológico no sedimento do Rio Jaguaribe/CE. Tese (Doutorado em Ciências Marinhas Tropicais) - Universidade Federal do Ceará, Fortaleza, 2018.

MORAIS, P. C. V.; GAMA, A. F.; FERNANDES, G. M.; OLIVEIRA, A. H. B.; LIMA, M. F. B.; SANTOS, F. R.; MARTINS, D. A.; NASCIMENTO, R. F.; CAVALCANTE, R. M.. Emerging and Traditional Organic Markers in Areas with Multiple Anthropogenic Activities: Development of an Analytical Protocol and Its Application in Environmental Assessment Studies. Bulletin of Environmental Contamination and Toxicology, v.102, n.1, p.66-76, 2019. DOI: https://doi.org/10.1007/s00128-018-2475-5 
NI, N.; YAGER, J. D.. The co-mitogenic effects of various estrogens for TGF- $\alpha$-induced DNA synthesis in cultured female rat hepatocytes. Cancer Letters, Virginia, v.84, n.2, p.133-140, 1994. DOI: https://doi.org/10.1016/03043835(94)90367-0

ÖRN, S.; HOLBECH, H.; NORRGREN, L.. Sexual disruption in zebrafish (Danio rerio) exposed to mixtures of $17 \alpha$ ethinylestradiol and $17 \beta$-trembolone. Environmental Toxicology and Pharmacology, Amsterdam, v.41, v.1, p.225231, 2016. DOI: https://doi.org/10.1016/j.etap.2015.12.010

OTTINGER, M. A.; BOHANNON, M.; CARPENTER, L.; CARRO, T.; ROCHESTER, J. R.; DEAN, K. M.. Actions of Toxicants and Endocrine-Disrupting Chemicals in Birds. In: SCANES, C. G.. Sturkie's Avian Physiology. 6 ed. Elsevier, 2015.

PANDIAN, T. J.; SHEELA, S. G.. Hormonal induction of sex reversal in fish. Aquaculture, London, v.138, n.1-4, p.1-22, 1995. DOI: https://doi.org/10.1016/0044-8486(95)01075-0

PASSOS NETO, O. C.; SANTOS, A. B.; SILVA, J. R. F.; MOTA, S. $B$.. Action of two endocrine disrupters on the sexual differenciation of Nile tilapia. Revista Ciência Agronômica, Fortaleza, v.50, n.3, p. 402-410. DOI: http://dx.doi.org/10.5935/1806-6690.20190048

PIMENTEL, M. F.; DAMASCENO, E. P.; JIMENEZ, P. C.; ARAÚJO, P. F. R.; BEZERRA, M. F.; MORAIS, P. C. V.; CAVALCANTE, R. M.; LOUREIRO, S.; LOTUFO, L. V. C.. Endocrine disruption in Sphoeroides testudineus tissues and sediments highlights contamination in a northeastern Brazilian estuary. Environmental Monitoring and Assessment, Dordrecht, v.188, n.5, p.188-298, 2016. DOI: 10.1007/s10661-016-5300-9

POJANA, G.; GOMIERO, A.; JONKERS, N.; MARCOMINI, A. Natural and synthetic endocrine disrupting compounds (EDCs) in water, sediment and biota of a coastal lagoon.Environment International, Elmsford, v.33, n.7, p.929-936, 2007. DOI: https://doi.org/10.1016/j.envint.2007.05.003

PRAVEENA, S. M.; RASHID, M. Z. M.; NASIR, F. A. M.; YEE, W. S.; ARIS, A. Z.. Occurrence and potential human health risk of pharmaceutical residues in drinking water from Putrajaya (Malaysia). Ecotoxicology and Environmental Safety, New York, v.180, n.1, p.549-556, 2019. DOI: https://doi.org/10.1016/i.ecoenv.2019.05.051

PRIMACK, R. B, RODRIGUES, E.. Biologia da conservação. Londrina: Planta, 2001.

PUSCEDDU, F. H.; SUGAUARA, L. E.; MARCHI, M. R.; CHOUERI, R. B.; CASTRO, I. B.. Estrogen levels on surface sediments from a multi-impacted Brazilian estuarine system. Marine Pollution Bulletin, Amsterdam, v.142, n.1, p.576580, 2019. DOI:

https://doi.org/10.1016/j.marpolbul.2019.03.052

RAO, K.; LEI, B.; LI, N.; MA, M.; WANG, Z.. Determination of estrogens and estrogenic activities in water from three rivers in Tianjin, China. Journal of Environmental Sciences, Amsterdam, v.25, n.6, p.1164-1171, 2013. DOI: https://doi.org/10.1016/S1001-0742(12)60149-1

REICHERT, K.; MENZEL, R.. Expression profiling of five different xenobiotics using a Caenorhabditis eleganswhole genome microarray. Chemosphere, Oxford, v.61, n.2, p.229237, 2005. DOI:

https://doi.org/10.1016/j.chemosphere.2005.01.077

REIS FILHO, R. W.; LUVIZOTTO-SANTOS, R.; VIEIRA, E. M.. Poluentes Emergentes como Desreguladores Endócrinos. Journal of the Brazilian Society of Ecotoxicology, Itajaí, v.2, n.3, p.283-288, 2007. DOI: 10.5132/jbse.2007.03.012

REN, D.; HUANG, H.; YANG, B.; PAN, X.; DIONYSIOU, D. D. Mitigating 17 aethynylestradiol water contamination through binding and photosensitization by dissolved humic substances. Journal of Hazardous Materials, Amsterdam, v.327, n.1, p.197-205, 2017. DOI: https://doi.org/10.1016/j.jhazmat.2016.12.054

RUNNALLS, T. J.; BERESFORD, N.; KUGATHAS, S.; MARGIOTTA-CASALUCI, L.; SCHOLZE, M.; SCOTT, A. P.. From single chemicals to mixtures: 60 Reproductive effects of levonorgestrel and ethinylestradiol on the fathead minnow. Aquatic Toxicology, Amsterdam, v.169, n.1, p.152-167, 2015. DOI: https://doi.org/10.1016/j.aquatox.2015.10.009

SALIERNO, J. D.; KANE, A. S.. 17alpha-ethinylestradiol alters reproductive behaviors, circulating hormones, and sexual morphology in male fathead minnows (Pimephales promelas). Environmental Toxicology and Chemistry, Hoboken, v.28, n.5, p.953-961, 2009. DOI: http://doi.org/10.1897/08-111.1

SALLA, R. F.; GAMERO, F. U.; RISSOLI, R. Z.; DAL-MEDICO, S. E.; CASTANHO, L. M.; CARVALHO, C. S.. Impact of an environmental relevant concentration of $17 \alpha-$ ethinylestradiol on the cardiac function of bullfrog tadpoles. Chemosphere, Oxford, v.144, n.1, p. 1862-1868, 2016. DOI: https://doi.org/10.1016/j.chemosphere.2015.10.042

SANTOS, F. R.; MARTINS, D. A.; MORAIS, P. C. V.; OLIVEIRA, A. H. B.; GAMA, A. F.; NASCIMENTO, R. F.. Science of the Total Environment, Amsterdam, v.656, n.1, p.877-888, 2019. DOI: https://doi.org/10.1016/i.scitotenv.2018.11.380

SCHREIBER, E.; ALFAGEME, O.; GARCIA, T.; GONZÁLEZ, N.; SIRVENT, J. J.; TORRENTE, M.. Food and Chemical Toxicology, Oxford, v.128, n.1, p.193-201, 2019. DOI: https://doi.org/10.1016/j.fct.2019.04.013

SILVA, E. G.; TORNOS, C.; DEAVERS, M.; KAISMAN, K.; GRAY, K.; GERSHENSON, D.. Induction of Epithelial Neoplasms in the Ovaries of Guinea Pigs by Estrogenic Stimulation.Gynecologic Oncology, New York, v.71, n.2, p.240-246, 1998. DOI: https://doi.org/10.1006/gyno.1998.5153

SKJAERLUND, J. M.. Estrogen protection against atherosclerosis and synthetic estrogen production of cirrhosis in the rabbit. Research Communications in Chemical Pathology and Pharmacology, New York, v.75, p.193-208, 1992

SMOLARZ, K.; HALLMANN, A.; ZABRZANSKA, S.; PIETRASIK, A.. Elevated gonadal atresia as biomarker of endocrine disruptors: Field and experimental studies using Mytilus trossulus (L.) and 17-alpha ethinylestradiol (EE2). Marine Pollution Bulletin, Amsterdam, v.120, n.1-2, p.58-67, 2017. DOI: https://doi.org/10.1016/j.marpolbul.2017.04.007 
TAN, R.; LIU, R.; LI, B.; LIU, X.; LI, Z.. Typical Endocrine Disrupting Compounds in Rivers of Northeast China: Occurrence, Partitioning, and Risk Assessment. Archives of environmental contamination and toxicology, New York, v.75, n.2, p.213-223, 2018. DOI:

http://doi.org/10.1007/s00244-017-0482-x

TOPPARI, J.. Introduction to Endocrine Toxicology and Endocrine Disruption.Encyclopedia of Endocrine Diseases (Second edition), Cambridge, v.1, n.1, p.762-763, 2019. DOI: https://doi.org/10.1016/B978-0-12-801238-3.64328-3

URAIPONG, C.; ALLAN, R. D.; LI, C.; KENNEDY, I. R.; WONG, V.; LEE, N. A.. A survey of $17 \alpha$-ethinylestradiol and mestranol residues in Hawkesbury River, Australia, using a highly specific enzyme-linked immunosorbent assay (ELISA) demonstrates the levels of potential biological significance. Ecotoxicology and Environmental Safety, New York, v.144, n.1, p.585-592, 2017 DOI:

https://doi.org/10.1016/i.ecoenv.2017.06.077

UN. United Nations. Contraceptive Use by Method 2019. New York: United Nations, 2019.

VOLKOVA, K.; CASPILLO, N. R.; PORSERYD, T.; HALLGREN, S.; DINNÉTZ, P.; PORSCH-HALLSTROM, I.. Developmental exposure of zebrafish (Danio rerio) to 17 aethinylestradiol affects non-reproductive behavior and fertility as adults, and increases anxiety in unexposed progeny. Hormones and Behavior, New York, v.73, n.1, p.30-38, 2015. DOI: https://doi.org/10.1016/j.yhbeh.2015.05.014

WANG, J.; ZHU, Y.. Occurrence and risk assessment of estrogenic compounds in the East Lake, China.

Environmental Toxicology and Pharmacology, Amsterdam, v.52, n.1, p.69-76, 2017. DOI:

https://doi.org/10.1016/i.etap.2017.03.018

WANG, Z.; LI, R.; WU, F.; FENG, C.; YE, C.; YAN, C.. Estrogenic compound profiles in an urbanized industry-impacted coastal bay and potential risk assessment by pollution indices and multivariative statistical methods. Marine Pollution Bulletin, Oxford, v.114, n.1, p.397-407, 2017 b. DOI: https://doi.org/10.1016/j.marpolbul.2016.09.050

WEIN, H.. Understanding How Testosterone Affects Men. National Institutes of Health. Bethesda, 2013.

XU, M.; HUANG, H.; LI, N.; LI, F.; WANG, D.; LUO, Q. Occurrence and ecological risk of pharmaceuticals and personal care products (PPCPs) and pesticides in typical surface watersheds, China. Ecotoxicology and
Environmental Safety, New York, v.175, n.1, p.289-298, 2019. DOI: https://doi.org/10.1016/i.ecoenv.2019.01.131

YANG, L.; CAO, X.; ZHANG, M.; WANG, J.. Occurrence and distribution of endocrine-disrupting compounds in the Honghu Lake and East Dongting Lake along the Central Yangtze River, China. Environmental Science and Pollution Research, Hong Kong, v.22, n.18, p.17644-17652, 2015. DOI: http://doi.org/10.1016/j.scitotenv.2009.06.002

YANG, L.; LIN, L.; WENG, S.; FENG, Z.; LUAN, T.. Sexually disrupting effects of nonylphenol and diethylstilbestrol on male silver carp (Carassius auratus) in aquatic microcosms. Ecotoxicology and Environmental Safety, New York, v.71, n.2, p.400-411, 2008. DOI: https://doi.org/10.1016/j.ecoenv.2008.01.007

YUAN, K.; KANG, H.; YUE, Z.; YANG, L.; LIN, L.; WANG, X.; LUAN, T.. Determination of 13 endocrine disrupting chemicals in sediments by gas chromatography-mass spectrometry using subcritical water extraction coupled with dispersed liquid-liquid microextraction and derivatization. Analytica Chimica Acta, Amsterdam, v.866, n.1, p.41-47, 2015. DOI: https://doi.org/10.1016/i.aca.2015.02.011

YUAN, S.; HUANG, C.; JI, X.; MA, M.; RAO, K.; WANG, Z.. Prediction of the combined effects of multiple estrogenic chemicals on MCF-7 human breast cancer cells and a preliminary molecular exploration of the estrogenic proliferative effects and related gene expression.

Ecotoxicology and Environmental Safety, New York, v.160, n.1, p.1-9, 2018. DOI: https://doi.org/10.1016/j.ecoenv.2018.05.025

ZHANG, X.; LI, Q.; LI, G.; WANG, Z.; YAN, C.. Levels of estrogenic compounds in Xiamen Bay sediment, China. Marine Pollution Bulletin, Amsterdam, v.58, n.8, p.12101216, 2009. DOI: https://doi.org/10.1016/j.marpolbul.2009.03.011

ZHANG, Z.; REN, N.; KANNAN, K.; NAN, J.; LIU, L.; MA, W.. Occurrence of endocrine-disrupting phenols and estrogens in water and sediment of the Songhua River, Northeastern China. Archives of Environmental Contamination and Toxicology, New York, v.66, n.3, p.361-369, 2014. DOI: http://doi.org/10.1007/s00244-014-9998-5

ZOU, E.; FINGERMAN, M.. Effects of Estrogenic Agents on Chitobiase Activity in the Epidermis and Hepatopancreas of the Fiddler Crab, Uca pugilator. Ecotoxicology and Environmental Safety, New York, v.42, n.2, p.185-190, 1999. DOI: https://doi.org/10.1006/eesa.1998.1740

A CBPC - Companhia Brasileira de Produção Científica (CNPJ: 11.221.422/0001-03) detém os direitos materiais desta publicação. Os direitos referem-se à publicação do trabalho em qualquer parte do mundo, incluindo os direitos às renovações, expansões e disseminaç̃̃es da contribuição, bem como outros direitos subsidiários. Todos os trabalhos publicados eletronicamente poderão posteriormente ser publicados em coletâneas impressas sob coordenação da Sustenere Publishing, da Companhia Brasileira de Produção Científica e seus parceiros autorizados. Os (as) autores (as) preservam os direitos autorais, mas não têm permissão para a publicação da contribuição em outro meio, impresso ou digital, em português ou em tradução. 